\title{
OORSIG
}

\section{DIE BEHOEFTES EN PROBLEME VAN DIE VROU MET KARSINOOM VAN DIE MAMMAE WAT VERBAND HOU MET PSIGOSOSIALE, EKONOMIESE, SEKSUELE EN GODSDIENSTIGE ASPEKTE}

\author{
N. C. van Wyk
}

\section{Opsomming}

Die behoeftes en probleme van die vrou met karsinoom van die mammae wat verband hou met psigososiale, ekonomiese, seksuele en godsdienstige aspekte

Blanke vroue met karsinoom van die mammae ervaar besondere behoeftes en probleme. Hierdie behoefies en probleme sentreer rondom psigososiale, ekonomiese, seksuele en godsdienstige aspekte. Verskeie etiologiese faktore is by die ontstaan van hierdie behoeftes en probleme betrokke. Afgesien van die spanning wat 'n diagnose van karsinoom en meer spesifiek 'n diagnose van karsinoom van die mammae teweegbring, dra die behandeling van karsinoom ook by tot die behoefies en probleme wat hierdie vroue ervaar.

Uit die navorsing blyk dit duidelik dat die meerderheid van die vroue nie erge probleme met die hantering van hulle siektes ervaar het nie. Die vroue het 'n universele lae gemiddelde intensiteir van behoeftes en probleme ondervind. Hulle het egter steeds hulp en ondersteuning benodig in die hantering en aanvaarding van die gevolge van karsinoom en die gepaardgaande behandeling.

\section{Summary}

The psychosocial economic, sexual and religious related needs and problems of women with carcinoma of the breast are explored.

White women with carcinoma of the breast experience particular needs and problems related to psychosocial, economic, sexual and religious matters. These needs and problems are also influenced by a number of aetiological factors. Apart from the tension caused by a diagnosis of carcinoma, and particularly one of carcinoma of the breash the treatment which these women receive contributes to their needs and problems.

The research clearly showed that the majority of women did not experience serious problems in coping with their illness - there was a universally low average intensity of needs and problems. They did, however, require help and support in coping with and accepting the consequences of the carcinoma and the attendant treatment.

\section{INLEIDING}

Ilicrdic besondere behoeftes van vrouc met karsinoom van die mammac word, afgesien van indiwiducle ctiologiese faktore, veroorsaak deur die spanning wat 'n diagnose van karsinoom en meer spesifick 'n diagnose van karsinoom van dic mammae, teweegbring. Die chroniese aard van karsinoom, tesame met die onsekerheid ten opsigte van die uitcinde daarvan, sowel as die gevolge van die behandeling van karsinoom van die mammae, is ewencens etiologiese faktore vir die genoemde behoeftes van hierdie groep pasiënte.

\section{LITERATUUROORSIG}

Behoeftes/probleme met betrekking tot inligting

Volgens verskeie navorsers en persone wat daagliks in die kliniese veld met pasiente wat karsinoom het, werksaam is, blyk dit duidelik dat hierdie pasiente meer inligting verlang met betrekking tot hulle siekte, tipe behandeling sowel as algemene reaksies en situasies wat hulle kan verwag.

Die waarde van inligting lê daarin dat onsekerheid te alle tye mocilik hanteertaar is. Die onbekende veroorsalak dikwels meer vrees as wat die bekende sou kon doen. King is van mening dat die afwesigheid van feitelike inligting, aanleiding gee tot mites en bygelowigheid wat op hul beurt angstigheid tot gevolg het. Sy is oortuig dat wanneer 'n pasient oor genoegsame feitelike inligting beskik gegewe sifuasies waarin sy haar mag bevind vir haar verkl aarbaar word, sodat sy beheer daaroor bekom. Sodoende word angs verminder (King 1984:51). Anderson (1988:39) staaf hierdie getuienis met sy bevinding dat pasiente wat genoeg voorbereiding voor bedreigende prosedures ontvang minder angs ervaar. 'n Gebrek aan inligting plaas die pasiënt in 'n magtelose situasie wat 'n moontlike verklaring bicd vir die angs wat sy in so 'n situasie ervaar. 'n Ondersoek van Hames en Stirling rugsteun hierdic verklaring. Ilulle het bevind dat 'n groep vroue wat chirurgie vir karsinoom van die mammac ondergaan het, nadat hulle volledig met betrekking tot behandelingsmoontlikhede ingelig is en in ' $n$ beperkte mate betrek is in die keuse van 'n behandelingsmetode, minder 
post-operatiewe depressie ondervind het as die ander groep vroue in hulle studie wat nie volledig ingelig is nie. Verder het eersgenoemde groep vroue ' $n$ baie beter fisieke selfbeeld gehad as die ander groep vroue (Hames en Stirling 1987:51).

'n Verdere voordeel wat die openlike bespreking van die pasiènı se diagnose, prognose en behandelingsmoontlikhede insluit, is dat daar geleenthede vir in diepte kommunikasie tussen die pasiènt, die gesondheidspersoneel en die pasient se gesin geskep word. Hierdeur word vermyding en gevolglike isolasie van die pasiènt voorkom. 'n Verdere voordeel van die genoemde kommunikasie blyk duidelik uit die navorsingsbevindinge van Funch en Mettlin (1982:95) naamlık dat pasiënte makliker aangepas het by die veranderde omstandighede wat lewecggcbring is deur chirurgie van die mammae omdat hulle voldoende kommunikasie met die gesondheidspersoneel gehad het.

Pasiente met karsinoom benodig nie net inligting spesifiek daaroor nie, maar weliswaar oor 'n reeks situasies wat direk of indirek verband hou met hulle siekte. Die inligting wat meestal verlang word, het betrekking op die diagnose en die lewensverwagting van die pasiênt. Met betrekking tot laasgenoemde het McIntosh (1976:301) bevind dat pasiènte met karsinoom nie spesifiek wil weet of hulle gaan sterf nie. Hulle wil vecl eerder weet wat die teenswoordige situasie is, en nie wal in die toekoms gaan gebeur nie. Morris en haar kollegas (1985:797) verskil egter van McIntosh en wys daarop dat pasiënte dikwels inligting verlang met betrekking tot die moonllikheid van dood. Allen (1981:198) is van mening dat die inligting wat 'n pasient met betrekking tot haar siekte benodig meestal daarop gerig is om wanopvattings uit die weg te ruim. Omdat pasiente wat in remissie verkeer ' $n$ vrees het vir die herhaling van karsinoom, word die behocfte aan inligting met betrekking tot moontlike herhaling dikwels deur hierdie pasiente genoem (Northouse 1984:227).

Verdere fakıore waaroor pasiênte kommer ervaar en dus inligting benodig is die behandeling wat vir hulle voorgeskryf is. Volgens Fredette en Beattie (1986:309) benodig hierdie pasiènte veral inligting met betrekking tot die newe-effekte wat hulle as gevol $g$ van die behandeling kan verwag sowel as die hanteringsmoontlikhede van die newe-effekte.

Op die psigososiale vlak benodig pasiënte met karsinoom volgens Morris en haar kollegas (1985:797) inligting oor die impak wat 'n diagnose van karsinoom op interpersoonlike verhoudinge mag hê. Voorts benodig pasiènte met karsinoom ook met betrekking tol die ekonomiese en seksucle aspekte van menswees inligting om sodoende probleme te kan hanteer en kommer te kan verlig (Fredette en Beattie 1986:309).
Behoeftes/probleme met betrekking tot ekonomiese stabiliteit

'n Diagnose van karsinoom bring direkte en indirekte finansiële uitgawes vir die pasiënt en haar gesin mee. Die direkte uitgawes hou verband met konsultasies, hospitalisasie en die bchandeling van die pasiënt terwyl die indirekte uitgawes verband hou met die verlaagde produktiwiteit van die pasiënt en addisionele huishoudelike uitgawes wat deur haar siekte genoodsaak word. Hierdie direkte en indirekte uitgawes kan daantoe lei dat 'n pasiënt met karsincom in 'n mindere of meerdere mate finansiele probleme ondervind. Funch en Mettlin wys daarop dat finansiële probleme die herstel van 'n vrou na chirurgie van die mammae, kan benadeel. Hulle is van mening dat finansičle probleme 'n pasiènt mag verhinder om mediese hulp te verkry wanneer sy post-operatiewe komplikasies ervaar. Dit mag verder daartoe lei dat sy nie 'n prostese aankoop en dra nie wat haar liggaamshecld en haar aanvaarding van die skending van haar liggaam negatief mag beinvlocd (Funch en Mettlin 1982:96).

Afgesien van die finansièlc uitgawes en gevolglike probleme wat sy mag ervaar beskou baie werkgewers ' $n$ vrou met karsinoom van die mammae as 'n finansiële risiko. Om hierdie rede word vroue met karsinoom verkieslik nie in diens geneem of gehou nie

Behoeftes/probleme met betrekking tot liefde, aanvaarding en omgang met ander

Elke persoon, ongeag ras, geslag, kultuur of ouderdom het volgens Smith (1978:171) nie net ' $n$ behoefte om lief te hê nie, maar ook om liefde te ontvang. Hicrdie behoefte kan ten beste in gesinsverband deur die individu uitgeleef word. Die indiwidu wat die voorteg het om haar in 'n gesin te bevind, behoort altyd as deel van ' gesin beskou te word, en nie as 'n losstaande indiwidu nie. Volgens Kaplan (1982:221) is die indiwidu om hierdie rede nie alleen verantwoordelik vir die hantering van haar probleme nie. Glacquinta (1977:1585) sluit hierby aan en is van mening dat die gesin die primêre ondersteuners van die indiwidu behoort te wees wanneer laasgenoemde haar in 'n krisis bcvind. Die indiwidu bevind haar egter nie net in die sosiale sisteem van 'n gesin nie, maar ook in ' $n$ bepaalde vriendekring. Beide hierdie groepe persone bied aan die indiwidu die geleentheid om licfde te gee en te ontvang sowel as om aanvaarding van, en omgang met hulle te belcef. Volgens Murawski en sy kollegas (1978:370) kan hierdie groepc persone cok die ondersteuning bied wat die persoon in 'n krisis mag benodig.

Die emosionele betrokkenheid van die gesin, familie en vriende by die pasiënt wat karsinoom het, is altyd 'n positiewe faktor omdat hulle daardeur aan die pasiênt die nodige ondersteuning kan bied wat sy nodig het om die krisis waarin sy haar bevind, te kan hanteer
Goldberg en Cullen (1985:805) sowel as Baltrusch en Waltz (1985:789) is dit eens dat sosiale ondersteuning soos verkry van gesinsen familielede en vriende 'n krities bepalende faktor is in die pasient se psigososiale aanpassing by die diagnose en siekteverloop van karsinoom. Hierdie bevindinge word bevestig deur die ondersoek van Funch en Mettlin (1982:91). Hulle het 'n sterk positiewe korrelasie gevind tussen die sosiale ondersteuning wat die pasiente met karsinoom van die mammae gekry het en hul psigologiese aanpassing na chirurgie. Volgens Flynn (1980:101) le die verklaring hiervoor daarin dat die pasient in die teenwoordigheid van sosiale ondersteuning die spanningsituasies waarmee sy gekonfronteer word as minder bedreigend ervaar.

Verder is Wortman (1984:2353) van mening dat die pasiěnt se hanteringsmeganismes meer effektief is in die teenwoordigheid van die ondersteuning van gesins-, familielede en vriende.

Die bestaande verhouding wat die indiwidu met haar gesin, familie en vriende beleef, word egter dikwels deur siekte versteur. Volgens Saunders en McCorkle beinvloed karsinoom die verhouding wat die pasiënt met haar gesin, familie en vriende het deurdat sy in die eerste plek nie die rolle kan vervul wat sy voorheen vervul het nie. Tweedens beleef sy 'n siekte waarvan die verloop haar sosiale funksionering negatief mag beinvloed. In die derde plek noodsaak haar siekte haar om baie swaar te leun op die ondersteuning wat haar gesin, familie en vriende aan haar kan bied (Saunders en McCorkle 1985:374).

\section{Behoeftes/probleme met betrekking tot} seksuele uitlewing

In die lig van die stelling van Morgan en Hart (1987:54) dat elke hospitiumprogram vir die versorging van karsinoom-pasiënte voorsiening behoor te maak vir die probleme wat rondom die seksuele behoeftes van die pasient ontstaan, kan aanvaar word dat daar dwarsdeur die siekteverloop aan hierdie probleme aandag gegee behoort te word. Ostchega en Jacob (1984:42) sluit hierby aan deur te sê dat wanneer die aanpassing van ' $n$ pasiënt by karsinoom meebring dat die normale verhouding tussen huwcliksmaats daardeur versteur word, die aanpassing nie as effektief beskou kan word nie.

Die voorkoms van seksuele veranderinge by die vrou met karsinoom van die mammae is te wyte aan fisieke en psigososiale faktore. Karsinoom kan net soos enige ander siektetocstand ' $n$ negatiewe effek op die seksuele aktiwiteite van die pasiente hê (Nevidjon 1984:260). In die geval van karsinoom van die mammae sal beenmetastases in die pelvis en werwelkolom erge pyn tot gevolg hê wat seksuele behoeftes inhibeer. Hierbenewens verswak metastases die beenweefsel sodat die bene van die pelvis en werwelkolom so breekbaar is dat sommige 
seksucle posisies gevaar vir die pasiènt inhou (Mantell 1982:237). Afgesien van dić dramatiese effek van karsinoom veroorsaak dit ook 'n recks endogene fisiologiese veranderinge wat seksuele funksionering kan beinvloed (Mantell 1982:236). Met betrekking tot die psigososiale aspekte bring karsinoom net scos ander sicktetoestande mee dat pasiente veranderinge in die rolle wat hulle vervul, ervaar, wat tot seksucle veranderinge aanleiding gec (Nevidjon 1982:260). Bykomend moet die pasiënte ook 'n nuwe rol, naamlik dié van pasiënt-wees wat ' $n$ ondergeskikte en relaticf passiewe rol is, aanlecr.

Die bchandelingsmoontlikhede van karsinoom van die mammae, namlik chirurgie, ioniserende bestraling en sitotoksiese chemoterapie, kan eweneens 'n negatiewe effek hê op die seksucle funksionering van die pasiënt. Beide ioniserende bestraling en chemoterapie het newe-effekte tot gevolg wat dirck of indirck tot seksuele veranderinge lei. In die geval van ioniscrende bestraling is die moegheid en naarheid wat dit meebring, belangrike oorsake van 'n verminderde belangstelling in seksuele aktiwiteite (Mantell 1982:237). Sitotoksiese chemoterapie veroorsaak ewencens ook naarheid, hraking en moegheid. Dit het ook dikwels alopesie, stomatitis en veranderinge in die vaginale slymvlies tot gevolg wat tot versteurings in die seksuele verhouding van die pasiënt met haar maat kan lei (Nevidjon 1984:272 en 273). Verder kan kalmeer-en antidepressiewe middels sowel as sommige narkotiese middels dic behocfte aan seksuele gemeenskap inhibeer (Mantell 1982:237 en 238).

Volgens Woods en Earp (1978:280) is die opsigtelike skending wat 'n mastektomie veroorsaak dic rede vir die scksuele versteurings wat met mastektomiee geassosieer word. Vroue interpreteer 'n mastektomie as 'n vernietiging van hul vroulikheid. Aansluitend by Woods en Earp se redes hoekom seksuele versteurings voorkom, is die redes wat Toughill aanvoer. Sy is van mening dat vroue verwerping vanweë hulle liggaamskending vrees en daarom nie in seksuele aktiwiteite betrokke wil raak nie. Sy wys egter ook verder op 'n rede wat op die fisicke aspek gerig is, naamlik dat vroue huiwerig is om seksucle aktiwiteite te hervat vanwee 'n vrees dat dic wond in dic proses beseer sal word (Toughill 1984:417).

Volgens Krumm (1982:735) is seksualiteit 'n komponent van die liggaamsbeeld van die pasiênt. Wanneer aanvaar word dat die verlies van 'n orgaan en spesifiek in hierdie geval die mamma, ' $n$ verandering in die liggaamshecld to gevolg het, kan aanvaar word dat 'n veranderde liggaamsbeeld veranderinge in seksuele funksionering tot gevolg sal hê. Woods stem met hierdie siening siam wanneer sy konstateer dat die intensiteit van 'n vrou se reaksic op 'n mastektomie bepaal word deur die waarde wat sy aan haar mammac heg. Sy maak die stelling dat ' $n$ vrou met buitengewoon groot of builengewoon klein mammae dic verlies van has mammac dikwels meer traumaties ervaar as dic vrou met normale grootte mammac (Meyerowitz 1980:114). Hieruit blyk dit duidelik dat dic pasient se siening van haar liggaam en die gevolglike unicke interpretasie van die skending bepaal of en tot watter mate versteurings in haar seksucle funksionering ervaar sal word

Andersen (1985:1835) wys verder daarop dat die depressie wat pasiënte dikwels met karsinoom ervaar ook 'n rede mag wees vir die teenwoordigheid van seksuele versteurings.

\section{Behoeftes/probleme met betrekking tot} skoonheid/beeld

'n Pasiënt ervaar 'n verandering in haar liggaamsbeeld wanneer haar siening van haar liggaam gedeeltelik of dramaties verander. So 'n verandering kan teweeggebring word deur veranderinge in en aan die liggaam. Die feit dat daar aan sekere liggaamsdele soos byvoorbeeld die mammae meer waarde geheg word, bring mec dat skending van hierdie dele 'n groter verandering in die liggaamsbecld van die pasient mecbring. Dic fisieke faktore wat 'n verandering in die liggaamsbeeld van ' $n$ vrou met karsinoom van die mammae kan teweegbring is in die eerste plek chirurgie van die mammae, en spesifiek 'n mastektomic (Maguire 1985:101) en die (weede plek die newe-efckte van sitotoksiese chemoterapie en ioniserende bestraling. Volgens Krumm (1982:732) het die newe-effekte van sitotoksiese chemoterapie 'n definitiewe negatiewe impak op die liggaamsbeeld van die pasient.

Veranderinge in die liggaamsbeeld bring spanning teweeg wat dikwels mocilik deur die pasiënt verwerk en hanteer word. In die geval van vroue met karsinoom van die mammac, veroorsaak die fisicke veranderinge wat hulle ervaar dat hulle dikwels minder aantreklik en minder vroulik voel. Verder tree hulle dikwels met minder sclfvertroue op en vermy hulle situasies waar hulle met dic onvol maaktheid van hulle liggame gekonfronteerkan word (Maguire 1985:101).

Behoeftes/probleme met betrekking tot beheer

Volgens Clarke ervaar 'n pasient behecr oor 'n situasie wanneer haar vermoë om dit te hanteer groter is as die cise wat die situasie aan haar stel (Sims 1986:583). Krisis-siluasies soos dié van sickte en hospitalisasie stel dikwels sulke groot cise aan die pasiēnt dat sy erg bewus word van die beperkinge van haar menswees en daardeur beheer oor haarself en haar omgewing verloor Volgens Wright (1985:10) vrees alle mense selfs gesonde mense - 'n siluasic waarin die persoon 'n verlies van beheer kan beleef, wat danleiding gee tol 'n gevoel van hulpeloosheid (Sims 1986:584) en afhanklikheid (Wright
1985: 10). Volgens Wright beleef die pasient erge angs, wanneer sy haar in 'n siluasie van athanklikheid bevind omdal daar van 'n persoon verwag word om dwarsdeur haar lewe juis te streef na onafhanklikhcid (Wright, 1985:10).

Volgens Skorupka en Bohnet ( 1982:371) kan 'n pasiënt slegs 'n hoë kwaliteit van lewe geniet wanneer sy toegelaat word om soveel en sover moontlik in beheer van haarself en haar omstandighede te bly. Ook Flynn (1980:101) is van mening dal die gevoel van in beheer wees, baie beslis ' $n$ positiewe effek het op die reaksies van 'n pasiënt binne situasies wat spanning tot gevolg kan hê. Seligman ondersteun hierdie bevinding met sy mening dat wanneer ' $n$ pasient aangelecrde hulpeloosheid ervaar, soos deur 'n gevoel van verlies van beheer, haar sensitiwiteit met betrekking tot depressie, siekte en selfs die dood verhoog (Hames en Stirling 1987:49). Hierteenoor wys Ostechega en Jacob (1984:45) daarop dat wanneer 'n pasiënt in beheer van die situasie is en dus minder sensitief vir emosionele stres is, sy meer dikwels van aktiewe probleem-oplossende hanteringsmeganismes gebruik maak.

\section{Behoeftes/probleme met betrekking tot godsdiens}

Volgens IFlorence Nightingale, soos aangehaal deur Simsen (1988:30) is die gees en dus die geestelike behoeftes wat die godsdienstige bchocftes van die mens insluit, van net soveel belang in die algemene gesondheid van die mens as die fisieke organe waaruit die liggaam saamgestel is. Aansluitend by hierdie siening, maar meer omvattend, is die mening van Labun (1987:314) wat reken dat die gees van die mens 'n aspek is van die totale mens wat elke aspek van menswees kan beinvloed. O'Brien (1982:89) wys voorts daarop dat daar 'n baie noue interaksie bestaan tussen die gees en die liggaam van die mens sodat 'n negatiewe belewenis van enigeen van hicrdie twee komponente 'n effek op die ander komponent sal kan hê.

Hierdie navorser wys in 'n ander geskrif verder daarop dat die mens, wanneer hy met die krisis van ernstige sickte gekonfronteer word dikwels ondersteuning soek in godsdiens (O'Brien 1982:69). Hierdie siening van O'Brien word deur Kivelt (1979:107) ondersteun in sy bevinding dat die godsdiens-georiënteerde gesteldheid en motivering van mense 'n ondersteunende krag in krisistye is. Murawski en sy kollegas (1978:370) wys verder daarop dat die kerk 'n belangrike komponent van die ondersteunende struktuur van elke mens is wat 'n krisis van siekte beleef. Meer spesifiek tot die krisis van karsinoom wys Goldberg en Cullen (1985:805) daarop dat verskeie navorsers en klinicse prakisyns dit eens is dat pasicnte wat aanspraak maak op 'n sterk godsdienslige ingesteldheid die krisis van karsinoom makliker verwerk en hanteer. Met betrekking tot die vrou met karsinoom is die mening van Devine (1980:680) van belang, naamlik dat vroue meer 
waarde as mans aan die godsdienstige aspek van hulle menswees heg. Hieruit kan afgelei word dat vroue met karsinoom baie swaar sal leun op hulle godsdiens in die verwerking en hantering van die krisis wat dit teweegbring.

Volgens Stoll (1979:1575) lê die rede vir die godsdienstige bewustheid van pasiënte in krisistye daarin dat die mens in hierdie tye besonder bewus is van sy eie beperkinge. Om hierdie rede soek hy dus na magte groter as hyself. Wright (1985:10) ondersteun hierdie siening. Sy is van mening dat die onbekendheid van die dood die pasiënt noop om vrae te vra soos: "Wat gaan van my siel word na dic dood?" Die pasiënt word dus gedwing om aan magte en situasies groter as hyself en sy onmiddellike omstandighede te dink. In hierdie tye dien godsdiens, volgens Reed (1986:35) as sekuriteit waarmee die onbekende en krisis aangedurf kan word.

\section{Die doelstellings van die studie}

Die doel van die studie is om die voorkoms en intensiteit van die behoeftes en probleme van die blanke vrou met karsinoom van die mammae wat verband hou met psigososiale, ekonomiese, seksuele en godsdienslige aspekte, te bepaal.

\section{Die afhakening van die studieveld}

Vanweë die invlocd wat kulturele verskille op die voorkoms en intensiteit van die genoemde behoeftes en probleme mag hê, is slegs blanke vroue in die ondersock ingesluit. Verder is die ondersoek beperk tot vroue wat hulle nie in die terminale stadium van hulle siekteverloop bevind het nie.

\section{TERMINOLOGIE}

Behoeftes en probleme

Vir die doeleindes van hierdie studie verwys behoeftes na dit wat elke mens in sy of haar daaglikse funksionering benodig, terwyl probleme verwys na onbeantwoorde behoeftes (kyk figuur 1).

\section{Kommer}

Vir die doel van hierdie studie dui kommer op 'n besorgdheid wat as of 'n behoefte of 'n probleem ervaar word. Wanneer 'n verpleegtussentrede daartoc lei dat besorgdheid, wat dikwels ook as onsekerheid ervaar word, gou uit die weggeruim word al vorens dit tot erge kommer en panick aanleiding gee, kan aanvaar word dat die besorgdheid slegs as 'n behoefte ervaar is. Wanneer aan die behoefte tot sekerheid ter hantering van kommer nie vrocgtydig aandag gegee word nie, lei dit tot'n ernstige probleem.

\begin{tabular}{|c|c|c|c|c|}
\hline 0 & 1 & 2 & 3 & 4 \\
\hline behoette atwesig & $\begin{array}{c}\text { behoette } \\
\text { teenwoordig }\end{array}$ & $\begin{array}{c}\text { behoefte is 'n } \\
\text { probleem }\end{array}$ & $\begin{array}{c}\text { behoette is 'n } \\
\text { groot probleem }\end{array}$ & $\begin{array}{c}\text { behoette is 'n } \\
\text { ernstige probleem }\end{array}$ \\
\hline
\end{tabular}

Figuur 1

Skaal vir die gradering van psigososiale, seksuele, godsdienstige en ekonomiese behoeftes en probleme

\section{DIE METODOLOGIE VAN NAVORSING}

'n Empiriese studic met 'n beskrywende navorsingsontwerp is gebruik.

$\mathrm{Na}$ afloop van die samestelling en ontwerp van die onderhoudsgids, is dit ter bepaling van die voorkomsgeldigheid daarvan aan geselektcerde domeinkundiges, wic oor spesiale opleiding en ondervinding op die gebied van onkologiese verpleegkunde beskik, vir evaluering voorgelê. Die onderhoudsgids is semi-gestruktureerd en bevat al die aspekte van kommer soos vervat in tabelle 1 tot 4 .

Daarna is onderhoude met vroue met karsinoom van die mammae gevoer om die voorkoms en intensiteit van hulle psigososiale, seksuele, ekonomiese en godsdienstige behoeftes en probleme te bepaal. Die vroue moes telkens self hulle behoeftes en probleme op 'n skaal van nul tot vier gradeer (kyk figuur 1).

Die onderhoude is gevoer deur die navorser bygestaan deur een veldwcrker wat ook 'n geregistreerde verpleegkundige is. Beide die navorser en die veldwerker beskik oor besondere ondervinding in onkologiese verpleging.

Die data wat verkry is, is met beskrywende statistiek verwerk.

\section{DIE STEEKPROEF}

In dic steekproefneming van die pasiente is van toevallige seleksie gebruik gemaak. Al die vroue met karsinoom van die mammae wat vanaf 10 Julie 1989 tot 8 September 1989 die Onkoterapeutiese kliniek en behandelingseenheid van die Nasionale Hospitaal in Bloemfontein besock het, of in dic Universitas en Nasionale Hospitale in Bloemfontein wat nie in die terminale stadium van hulle siekteverloop verkeer het nie, is in die steekproef ingesluit. Vyf-en-sestig vrouc is ingesluit.

Tien van die 65 vroue het chirurgie ondergaan, terwyl 'n verdere 10 vroue die Onkoterapie-kliniek terwille van opvolgondersoeke besoek het. Agtien van die 65 vroue het joniserende radioterapie en 27 sitotoksiese chemoterapie ontvang.

\section{BEVINDINGS EN INTERPRETASIE VAN DATA}

Voorkomsgeldigheid van die
onderhoudsgids

Slegs een domeinkundige was van mening dat enkele items uit die gids weggelaat kan word. Dit het spesifiek betrekking op geloofsekerheid. Omdat die ander sewe domeinkundiges egter van mening was dat dit wel ingesluit moes word, is dit behou. Vanweë die oorweldigende positiewe reaksie van die domeinkundiges is verdere inferensiële statistiese ontledings soos die Kuder-Richardson-formule, op aanbeveling van 'n slatistikus nie gedoen nie.

\section{DATA VERKRY MET ONDERIIOUDE}

\section{Sosiografiese data}

Die vroue wat in die ondersoekgroep ingesluit is, was hoofsaaklik ouer dames. Die modus-ouderdom was 61 jaar, hoewel die jongste vrou wat in die ondersoekgroep ingesluit is, slegs 28 jaar oud was. Die meerderheid van die vroue het hoërskoolopleiding ontvang terwyl 15 vroue $(23,1$ persent) kollege- en vier vroue $(67,2$ persent) universiteitsopleiding ontvang het. Nege-en-dertig vroue ( 60 persent) het ten tye van die ondersoek nie buitenshuise arbeid verrig nic. Hierdie vroue was reeds 'n geruime tyd huisvroue en het dus nie as gevolg van hulle karsinoom besluit om buitenshuise arbeid te staak nic.

Slegs 37 vroue $(56,9$ persent $)$ het aan 'n mediese hulpfonds behoort.

Drie-en-veertig vroue $(66,1$ persent) was ten tyc van die ondersoek getroud. Net een persoon was van haar man geskei, terwyl al die ander vroue weduwees was.

N die vroue het aan 'n Christelike kerk behoort, terwyl 25 vroue $(38,5$ persent) ook aktief betrokke by kerklike verenigings was. By kulturele verenigings was 15 vroue $(23,1$ persent) betrokke en by sosiale verenigings 14 vroue $(21,5$ persent). Vanuit die vroue se betrokkenheid by bogenoemde verenigings kan anvaar word dat hulle in krisistye ook uit hierdie verenigings ondersteuning sal ontvang.

Die stadiumbepaling van die vroue se karsinoom het gevarieër tussen die twee uiterstes, naamlik $\mathrm{T}_{1} \mathrm{~N}_{0} \mathrm{M}_{0}$ en $\mathrm{T}_{4} \mathrm{~N}_{3} \mathrm{M}_{1}$. 
Vyf-en-veertig vroue $(69,3$ persent) se karsinoom het gevarieër tussen $\mathrm{T}_{1} \mathrm{~N}_{0} \mathrm{M}_{0}$ en $\mathrm{T}_{2} \mathrm{~N}_{1} \mathrm{M}_{0}$. 'n Groot persentasie van die vroue het dus minder gevorderde karsinoom gehad

Die voorkoms en intensiteit van psigososiale, ekonomiese, seksuele en godsdienstige behoeftes en probleme

In die beskouing van die frekwensies van die behoeftes en probleme wat geidentifiseer is, blyk dit dat kommer oor karsinoom beduidend meer voorgekom het in vergelyking met die ander behoeftes en probleme (kyk tabelle 1 tot 4). Voorts blyk dit dat hierdie kommer nie net beperk is tot die vroue wat ten tye van die ondersoek behandeling ontvang het nie. Die vroue wat die kliniek terwille van opvolgondersoeke besoek het, het kommer oor 'n moonilike hervatting van hulle karsinoom ervaar (kyk tabel 1).

Anders as wat algemeen verwag word, het nie 'n groot persentasie van die vroue kommer oor hulle behandeling in die algemeen ervaar nie. 'n Moontlike rede hiervoor is die feit dat dic meeste van die vroue ten tye van die ondersoek reeds behandeling ondergaan het. Hulle het dus nie meer onsekerheid oor die newe-effekte en prosedure van bchandeling ervaar nie (kyk tabel 1).

Vanweè die herhaling van die diagnostiese en evaluerende prosedures, was hierdie prosedures redelik bekend aan die vroue. Min vroue het dus kommer of onsekerheid oor die gebeure tydens die prosedures ervaar. Negentien (29 persent) pasiente het egter aangedui dat dit vir hulle van groot belang is om die uitslae van al die prosedures te verneem (kyk tabel 1 )

Min pasiènte het kommer oor hulle beroeps- en finansiële posisie ervaar. 'n Rede hiervoor is die groot persentasie van die vroue wat nie in buitenshuise arbeid betrokke was nie. Hulle het hulle dus nie in 'n posisie bevind om 'n inkomste as gevolg van hulle karsinoom te verloor nie. Die koste van reise van en na die hospitaal het tot kommer by tien vroue $(15,4$ persent) gelei (kyk tabel 2)

Vanweë die hoe gemiddelde ouderdom van die vroue wat in hierdie ondersoek ingesluit is, het slegs ses van die vroue $(9,2$ persent) kommer oor die versorging van hulle kinders ervaar (kyk tabel 1). Meer vroue het egter veranderinge in die gesprekke met hulle kinders geverbaliseer

Agt vroue $(12,3$ persent) het kommer oor die ontbloting van hulle liggame aan hulle vriende en eggenote ervaar, terwyl 15 vroue $(23,1$ persent) kommer en onsekerheid oor prosteses ervaar het (kyk tabel 3). Die vroue wat ten tye van die ondersoek in die pre- en postoperaticwe fase was, het meer kommer oor hulle seksuele vitlewing as die ander vroue ervaar.

Hoewel die vroue 'n defnitiewe verandering in hulle omgang met ander mense ervaar hel, het
Tabel 1

Kommer/onsekerheid oor psigososlale aspekte by proefpersone $(\mathbf{N}=\mathbf{6 5})$

\begin{tabular}{|c|c|c|c|c|}
\hline \multirow{2}{*}{$\begin{array}{l}\text { ASPEKTE VAN KOMMER } \\
\text { Kommer oor karainoom }\end{array}$} & \multicolumn{4}{|c|}{$\begin{array}{l}\text { PROEFPERSONE SE GRADERING VAN } \\
\text { KOMMER ERVAAR }\end{array}$} \\
\hline & 1 & 2 & 3 & 4 \\
\hline Fisieke lekens van karsinoom & $13,8 \%$ & $3,1 \%$ & $3,1 \%$ & $1,5 \%$ \\
\hline Siekleverloop van karsinoom & $23,1 \%$ & $32,3 \%$ & $10,8 \%$ & $4,6 \%$ \\
\hline Hervatting van karsinoom & $16,9 \%$ & $32,3 \%$ & $2,3 \%$ & $4,6 \%$ \\
\hline Kommer oor aard en omvang behandeling & 1 & 2 & 3 & 4 \\
\hline Effektiwiteit van behandeling & $12,3 \%$ & $16,9 \%$ & $7,7 \%$ & $1,5 \%$ \\
\hline Chirurgie - skending van liggaam & $4,6 \%$ & $4,6 \%$ & - & - \\
\hline Chirurgie - dood tydens narkose & $1,5 \%$ & - & - & - \\
\hline Radioterapie - beplande behandelingskedule & $6,2 \%$ & $6,2 \%$ & - & - \\
\hline Radiolerapie werking & $4,6 \%$ & $6,2 \%$ & $1,5 \%$ & - \\
\hline Radioterapie prosedure & $4,6 \%$ & $3,1 \%$ & - & - \\
\hline Radiolerapie newe-effekte & $4,6 \%$ & $7,7 \%$ & $1.5 \%$ & - \\
\hline Radiolerapie verblyt tydens behandeling & - & $4,6 \%$ & $1,5 \%$ & - \\
\hline Radiolerapie vervoer van en na hospitaal & - & $1,5 \%$ & - & - \\
\hline Chemoterapie beplande behandelingskedule & $4,6 \%$ & $10,8 \%$ & $3,1 \%$ & $1,5 \%$ \\
\hline Chemoterapie werking & $7,7 \%$ & $7,7 \%$ & $1,5 \%$ & $3,1 \%$ \\
\hline Chemoterapie prosedure & $3,1 \%$ & $6,2 \%$ & $1,5 \%$ & $1,5 \%$ \\
\hline Chemoterapie newe-effekle & $6,2 \%$ & $13,8 \%$ & $4,6 \%$ & $3,1 \%$ \\
\hline Chemoterapie verblyf tydens behandeling & - & $4,6 \%$ & $1,5 \%$ & - \\
\hline Chemoterapie vervoer van en na hospitaal & - & - & - & $1,5 \%$ \\
\hline $\begin{array}{c}\text { Kommer oor aard en omvang diagnostiese } \\
\text { prosedure }\end{array}$ & 1 & 2 & 3 & 4 \\
\hline Teenswoordige prosedure - doel & $4,6 \%$ & $3,1 \%$ & $1,5 \%$ & - \\
\hline Teenswoordige prosedure - gebeure & $4,6 \%$ & - & - & - \\
\hline $\begin{array}{l}\text { Teenswoordige prosedure - moontlike nadelige } \\
\text { gevolge }\end{array}$ & $3,1 \%$ & $1,5 \%$ & - & - \\
\hline $\begin{array}{l}\text { Teenswoordige prosedure - ervaringe soos } \\
\text { ongemak en pyn }\end{array}$ & $10,8 \%$ & $1,5 \%$ & - & - \\
\hline $\begin{array}{l}\text { Teenswoordige prosedure - beskikbaarheid } \\
\text { van uitslae }\end{array}$ & $9,2 \%$ & $13,8 \%$ & $1.5 \%$ & $4,6 \%$ \\
\hline Toekomstige prosedures - frekwensie & $6,2 \%$ & $1,5 \%$ & $3,1 \%$ & $1,5 \%$ \\
\hline Toekomstige prosedures - tipe & $9.2 \%$ & - & $1,5 \%$ & - \\
\hline Toekomstige prosedures - noodsaaklikheid & $6,2 \%$ & $1.5 \%$ & $1,5 \%$ & $1,5 \%$ \\
\hline Kommer oor skoonheld/beold & 1 & 2 & 3 & 4 \\
\hline Verminderde vroulikheid & $15,4 \%$ & $10,8 \%$ & $3,1 \%$ & $4,6 \%$ \\
\hline Verminderde waardigheid & $6,2 \%$ & $15,4 \%$ & $6,2 \%$ & $3,1 \%$ \\
\hline Skending van liggaam & $9,2 \%$ & $9,2 \%$ & $3,1 \%$ & $1,5 \%$ \\
\hline Onaangename reuke & $1,5 \%$ & - & - & - \\
\hline Kommer oor verandering in sosiaie verikeer & 1 & 2 & 3 & 4 \\
\hline $\begin{array}{l}\text { Verminderende en veranderende sosiale } \\
\text { verkeer van die gesin }\end{array}$ & $4,6 \%$ & $1,5 \%$ & - & - \\
\hline Verminderende besoeke van familielede & $9,2 \%$ & $1,5 \%$ & - & - \\
\hline Verminderende besoeke van vriende & $4,6 \%$ & $3,1 \%$ & - & - \\
\hline Veranderende optrede van familielede & $4,6 \%$ & - & $1,5 \%$ & - \\
\hline Veranderende optrede van vriende & $7,7 \%$ & $4,6 \%$ & - & - \\
\hline $\begin{array}{l}\text { Negatiewe reaksie van familielede m.b.t. } \\
\text { karsinoom }\end{array}$ & $3,1 \%$ & - & $1.5 \%$ & - \\
\hline $\begin{array}{l}\text { Negatiewe reaksie van vriende m.b.t. } \\
\text { karsinoom }\end{array}$ & $4,6 \%$ & $3.1 \%$ & - & - \\
\hline
\end{tabular}

Curationis, Vol. 15, No. 1, 1992 
nie cen van die vroue dit as 'n ernstige probleem ervaar nie. Agt vroue (12,3 persent) het 'n verandering in die optrede van hulle vriende ervaar, terwyl sewe vroue $(10,8$ persent) verminderde besoeke van familielede ondervind het (kyk tabel 1).

Met betrekking tot kommer oor skoonheid het 22 vroue $(33,8$ persent) aangedui dat hulle kommer oor hulle verminderde vroulikheid ervaar het, terwyl 20 vroue $(30,8$ persent) kommer oor verminderde waardigheid geverbaliseer het (kyk tabel 1).

In die afdeling oor kommer oor verlies van beheer het 21 vroue $(32,3$ persent) kommer oor die maligne groei in hulle liggame ervaar. Voorts het 25 vroue $(33,8$ persent) kommer oor hulle toekoms ervaar terwyl agt vroue $(12,3$ persent) kommer oor hulle posisie in hulle gesinne ervaar het ( $k y k$ tabel 1 ). Hierdie kommer het hoofsaaklik gesentreer rondom die moontlikheid dat hulle op een of ander stadium afhanklik van ander persone sal wees.

Een-en-twintig vroue $(32,3$ persent) het probleme oor die geregtigheid van God ervaar, terwyl ses vroue $(9,2$ persent) probleme oor die liefde van God ervaar het (kyk tabel 4).

\section{GEVOLGTREKKING}

Uit tabelle 1 tot 4 blyk dit duidelik dat die vroue 'n universele lae gemiddelde intensiteit van behoeftes en probleme ervar het. Dit is in ooreenstemming met die navorsingsbevindinge van Silberbarb, Maurer en Crouthamel (1980:454) sowel as dié van Weisman en Worden (1976-77:8). In beide hierdie twee navorsingsprojekte is gevind dat vroue met karsinoom van die mammae nie erge probleme met die hantering van hulle siekte ervaar het nic. Hulle het verder ook bevind dat die vroue nie spesifieke en dikwels dramatiese optredes van die gesondheidspersoneel benodig het nie.

\section{AANBEVELINGS}

Met hierdie studic is gepoog om 'n volledige beeld te verkry van die psigososiale, seksuele, godsdienstige en ekonomiese behoeftes en probleme wat vroue met karsinoom van die mammae ervaar. Die doel hiervan is om verpleegkundiges betrokke by die verpleging van hierdie vroue bedag te maak op die behoeftes wat hierdie vroue ondervind en die probleme wat daaruit voortspruit. Deur bewus te wees van die behoeftes en probleme word geleentheid tot volledige beraming gebied. Dit lei daartoe dat omvattende verpleegsorg verleen word deurdat al die psigososiale, seksuele, godsdienstige en ekonomiese behoeftes en probleme van hierdie vroue aangespreek word.

\section{BEPERKINGS}

Slegs blanke vroue is in die ondersoekgroep ingesluit. Hoewel dit vanuit verwagte kulturele verskille gedoen is, is dit ' $n$ beperking van die

\begin{tabular}{|c|c|c|c|c|}
\hline \multirow{2}{*}{$\begin{array}{l}\text { ASPEKTE VAN KOMMER } \\
\begin{array}{l}\text { Verandering in die gesprekke tussen gesin en } \\
\text { familielede }\end{array}\end{array}$} & \multicolumn{4}{|c|}{$\begin{array}{c}\text { PROEFPERSONE SE GRADERING VAN } \\
\text { KOMMER ERVAAR }\end{array}$} \\
\hline & $1,5 \%$ & - & $1,5 \%$ & - \\
\hline $\begin{array}{l}\text { Verandering in die gesprekke tussen gesiri en } \\
\text { vriende }\end{array}$ & $3,1 \%$ & $1,5 \%$ & - & - \\
\hline Verandering in verhouding met familielede & $6,2 \%$ & - & $1,5 \%$ & - \\
\hline Verandering in verhouding met vriende & $4,6 \%$ & $3,1 \%$ & - & - \\
\hline $\begin{array}{l}\text { Kommer oor verendering In } \\
\text { geoineverhouding }\end{array}$ & 1 & 2 & 3 & 4 \\
\hline $\begin{array}{l}\text { Veranderde verhouding tussen moeder en } \\
\text { kinders }\end{array}$ & $3,1 \%$ & $3,1 \%$ & $1.5 \%$ & - \\
\hline Verandering in versorging van kinders & - & $4,6 \%$ & $4,6 \%$ & - \\
\hline Verandering in opvoeding van kinders & $1,5 \%$ & $1,5 \%$ & $1,5 \%$ & - \\
\hline $\begin{array}{l}\text { Verandering in fisieke kontak tussen moeder } \\
\text { en kinders }\end{array}$ & $1,5 \%$ & - & $1,5 \%$ & - \\
\hline $\begin{array}{l}\text { Verandering in gesprekke tussen moeder en } \\
\text { kinders }\end{array}$ & $6,2 \%$ & $4,6 \%$ & $1,5 \%$ & - \\
\hline $\begin{array}{l}\text { Verandering in sosiale verkeer tussen moeder } \\
\text { en kinders }\end{array}$ & $4,6 \%$ & $4,6 \%$ & - & - \\
\hline $\begin{array}{l}\text { Verandering in sosiale verkeer tussen ouers en } \\
\text { kinders }\end{array}$ & - & - & - & - \\
\hline $\begin{array}{l}\text { Verandering in algemene optrede van die } \\
\text { kinders }\end{array}$ & $6,2 \%$ & $3.1 \%$ & $4,6 \%$ & - \\
\hline $\begin{array}{l}\text { Verandering in die optrede van kinders teenoor } \\
\text { mekaar }\end{array}$ & $4.6 \%$ & $1,5 \%$ & - & - \\
\hline $\begin{array}{l}\text { Negatiewe reaksie van die kinders m.b.t. } \\
\text { karsinoom }\end{array}$ & $6,2 \%$ & $1,5 \%$ & $3.1 \%$ & - \\
\hline Kommer oor veriies van beheer & 1 & 2 & 3 & 4 \\
\hline Maligne groei & $18,5 \%$ & $13,5 \%$ & - & - \\
\hline $\begin{array}{l}\text { Gebrekkige inligting m.b.t. siekteverloop, } \\
\text { prognose ens. }\end{array}$ & $7,7 \%$ & $7.7 \%$ & $3,1 \%$ & - \\
\hline Onsekerheid oor eie toekoms & $7,7 \%$ & $16,9 \%$ & $4,6 \%$ & $4,6 \%$ \\
\hline Onsekerheid oor posisie in gesin & $3,1 \%$ & $4,6 \%$ & $3.1 \%$ & $1,5 \%$ \\
\hline Onsekerheid oor posisie in gemeenskap & - & $6.2 \%$ & - & - \\
\hline Irritasie met hospitaalroetines & $4,6 \%$ & $6,2 \%$ & - & - \\
\hline $\begin{array}{l}\text { Irritasie met ondergeskikte posisie van } \\
\text { pasiëntrol }\end{array}$ & $6,2 \%$ & $1.5 \%$ & $1.5 \%$ & - \\
\hline $\begin{array}{l}\text { Irritasie met aanspreekvorm wat hospitaal } \\
\text { personeel gebruik }\end{array}$ & $1.5 \%$ & - & - & - \\
\hline
\end{tabular}

Tabel 2

Kommer/onsekerheid by proefpersone oor beroeps- en finansiële aangeleenthede $(N=65)$

\begin{tabular}{|l|c|c|c|c|}
\hline \multicolumn{1}{|c|}{$\begin{array}{c}\text { BEROEPS- EN FINANSÏLE AAN } \\
\text { GELEENTHEDE }\end{array}$} & \multicolumn{4}{c|}{$\begin{array}{c}\text { PROEFPRSONE SE GRADERING VAN } \\
\text { KOMMER ERVAAR }\end{array}$} \\
\cline { 2 - 6 } & 1 & 2 & 3 & 4 \\
\hline $\begin{array}{l}\text { Uitputting van siektevertofvoordele of gebrek } \\
\text { dearaan }\end{array}$ & $4,6 \%$ & $4,5 \%$ & - & - \\
\hline Koste van behandeling & $7,7 \%$ & $9,2 \%$ & - & - \\
\hline Gedwonge verandering van beroep & $1,5 \%$ & $1,5 \%$ & - & - \\
\hline Moontlike verlies van inkomste & $1,5 \%$ & $1,5 \%$ & - & - \\
\hline Koste van reise van en na hospitaal & $7,7 \%$ & $7,7 \%$ & - & - \\
\hline Uitpulting van mediese hulpskema voordele & $6,2 \%$ & $1,5 \%$ & - & - \\
\hline Gedwonge beëindiging van beroep & - & $3,1 \%$ & - & - \\
\hline $\begin{array}{l}\text { Veranderende houding en optrede van kol- } \\
\text { legas en werkgewer }\end{array}$ & - & - & - & - \\
\hline Onsimpatieke werkgewer & - & - & - & - \\
\hline
\end{tabular}


Tabel 3

Kommer/onsekerheld by proefpersone oor seksuele ult lewing $(N=65)$

\begin{tabular}{|l|c|c|c|c|}
\hline \multirow{2}{*}{ SEKSUELE UITLEWING } & \multicolumn{4}{|c|}{ PROEFERSONE SE GRADERING } \\
\cline { 2 - 5 } & 1 & 2 & 3 & 1 \\
\hline $\begin{array}{l}\text { Negatiewe reaksie van eggenoot/vriend } \\
\text { m.b.t.veranderde voorkoms }\end{array}$ & $1,5 \%$ & $1,5 \%$ & $1,5 \%$ & $3,1 \%$ \\
\hline $\begin{array}{l}\text { Negatiewe reaksie van eggenootwriend m.b.t. } \\
\text { chroniese siekwees van eggenote/vriendin }\end{array}$ & $3,1 \%$ & $6,2 \%$ & $1,5 \%$ & $1,5 \%$ \\
\hline $\begin{array}{l}\text { Negatiewe reaksie van eggenootvriend m.b.t. } \\
\text { karsinoom }\end{array}$ & $3,1 \%$ & $4,6 \%$ & - & - \\
\hline $\begin{array}{l}\text { Pasiënt se onvermoë om haar veranderde } \\
\text { voorkoms te aanvaar }\end{array}$ & $6,2 \%$ & $1,5 \%$ & - & - \\
\hline Ontbioting van liggaam aan eggenoot/vriend & $3,1 \%$ & $4,6 \%$ & $1,5 \%$ & $3,1 \%$ \\
\hline Hervatting van seksuele gemeenskap & $3,1 \%$ & $1,5 \%$ & - & - \\
\hline Verandering in seksuele gemeenskap & $1,5 \%$ & - & - & $1,5 \%$ \\
\hline Kleding & $3,1 \%$ & $7,7 \%$ & $1,5 \%$ & $3,1 \%$ \\
\hline Prostesis & $9,2 \%$ & $10,8 \%$ & $1,5 \%$ & $1,5 \%$ \\
\hline Swakker identifikasie van dogter met moeder & $1,5 \%$ & - & - & - \\
\hline $\begin{array}{l}\text { Veranderende optrede en/of aanvaarding van } \\
\text { seun teenoor moeder }\end{array}$ & - & $1,5 \%$ & $1,5 \%$ & - \\
\hline Kontrasepsie & $3,1 \%$ & $1,5 \%$ & - & - \\
\hline Fertiliteit & - & - & - & - \\
\hline Mamma rekonstruksie & $4,6 \%$ & $1,5 \%$ & - & - \\
\hline
\end{tabular}

Tabel 4

Kommer by proefpersone oor geloofsekerheid $(N=65)$

\begin{tabular}{|l|c|c|c|c|}
\hline \multirow{2}{*}{ ONSEKERHEID OOR GELOOF SEKERHEID } & \multicolumn{4}{|c|}{$\begin{array}{c}\text { PROEPERSONE SE GRADERING } \\
\text { VAN KOMMER ERVAAR }\end{array}$} \\
\cline { 2 - 5 } & 1 & 2 & 3 & 4 \\
\hline Onsekerheid sor die aanwesigheid van God & $3,1 \%$ & $1,5 \%$ & - & $1,5 \%$ \\
\hline Onsekerheid oor die liefde van God & $3,1 \%$ & $3,1 \%$ & $3,1 \%$ & $3,1 \%$ \\
\hline Onsekerheid oor die geregtigheid van God & $13,8 \%$ & $9,2 \%$ & $6,2 \%$ & $3,1 \%$ \\
\hline Onsekerheid oor die almag van God & $1,5 \%$ & $3,1 \%$ & - & - \\
\hline Onsekerheid oor die ewige lewe & $1,5 \%$ & - & - & - \\
\hline Onsekerheid oor die belekenis van lewe & $3,1 \%$ & - & $1,5 \%$ & $1,5 \%$ \\
\hline $\begin{array}{l}\text { Onsekerheid oor haar behoud as beelddraer } \\
\text { van God }\end{array}$ & $4,6 \%$ & - & $1,5 \%$ & - \\
\hline
\end{tabular}

studic. 'n Navorsingsprojek waartydens spesifiek gelet word op die voorkoms en intensiteit van die behoeftes en probleme soos deur vroue in ander etnicse groeperinge ondervind word, is noodsaaklik.

Aangesien slegs gelet is op die voorkoms en intensiteit van die behoeftes en probleme wat ondervind is, sal 'n verdere navorsingsprojek wat spesifiek gerig word op die identifisering van die hulp en ondersteuning wat hierdie vroue benodig, waardevolle inligting bied. Hierdeur sal die verpleegsorg aan hierdie pasiënte verbeter kan word.

\section{BIBLIOGRAFIE}

Al.LEN A. 1981. Psychosocial factors in cancer. American Family Physician, 23:197-201.

morbidity among cancer survivors: Curren status and future research directions Cancer, 55(8): 1835-1842.

ANDERSON, J. 1988. Coming to terms with mastectomy. Nursing Times, 84(4):41-44.

BATTRUSCH, H.J.F. AND WALTZ, M. 198. Cancer from a biohchavioural and social epidemiological perspective. Social Science in Medicine, 20(8):789-794. Nursing, o(11):679-687.

IFLYNN, P.A.R. 1980. The healing continuum Journeys in the philosophy of holistic health Communications $\mathrm{Co}$
FREDETIE, S.L. AND BEATITE, H.M. 1986 Living with cancer: a patient education program. Cancer Nursing, 9(6):308-316.

FUNCH, D.P. AND METTLIN, C. 1982. The role of support in relation to recovery from breast surgery. Social Science and Medicine, 16:91-98.

GIACQUINTA, B. 1977. Helping families face the crisis of cancer. American Journal of Nursing, 77(10):1585-1588.

GOLDBERG, R.J. AND CULLEN, L.O. 1985 Factors important to psychosocial adjustment to cancer: $A$ review of the evidence. Social Science and Medicine, 20(8):803-807.

HAMES, A. AND STIRLING, E. 1987. Choice aids recovery. Nursing Times, 83(8):49-51

KAPLAN, D.M. 1982. Intervention strategies for families in psychosocial aspects of cancer. New York: Raven Press.

KING, J. 1984. A question of attitude. Nursing Times, 80(4.5): 51 en 52.

KJVETT, V.R. 1979. Religious motivation in middle age: Correlates and implications Journal of Gerontology, 34(1): 106-115.

KRUMM, S. 1982. Psychosocial adaptation of the adult with cancer. Nursing Clinics of North America, 17(4):729-736

LABUN, E. 1988. Spritual care: An element in nursing care planning. Journal of Advanced Nursing 13(3):314-320.

MAGUIRE, P. 1985. The psychological impact of cancer. British Journal of Hospital Medicine, Augustus, 100-103.

MANTELL, J.E. Sexuality and cancer. In Pschosocial aspects of cancer. Ed. by Cohen, J. et.al. New York: Raven Press, 235-248.

McINTOSH, J. 1976. Patients' awareness and desire for information about diagnosed but undisclosed malignant disease. The Lancet, August, 300-303

DEVINE, B.A. 1980. Attitudes of the elderly toward religion. Journal of Gerontological Maryland: A Prentice-l lall Publishing and
MEYEROWITZ, B.E. 1980. Psychosocial correlates of breast cancer and its treatments. Psychological Bulletin, 87(1):108-131

MORGAN, C.O. AND HART, K. 1987. Organizing the psychosocial care of hospice patients. Nursing Management, 18(4):54-57.

MORRIS, T., BLAKE, S. AND BUCKLEY, B. 1985. Development of a method for rating cognitive responses to a diagnosis of cancer. Social Science and Medicine, 20(8):795-802

MURAWSKI, B.J., PENMAN, D. \& SCIIMITT, M. 1978. Social support in health and illness: the concept and its measurement. Cancer Nursing, 5:365-371. 
NI:VIDJON, B. 1982. Sexuality. In Cancer Nursing: A developmental approach. Fd. by Mclntire, S.N. and Cioppa, A.L. New York: John Wiley and Sons, 257-276.

NIEVIDJON, B.M. 1984. Chemotherapy. In Cancer Nursing: A developmental approach. Id. by McIntire, S.N. and Cioppa, A.L. New York: John Wiley and Sons, 115-145.

NOR'THOUSE, L. 1984. The impact of cancer on the family: An overview. International Journal of Psychiatry in Medicine, 14(3):21.5-242.

O'BRIEN, M.E. 1982. The need for spiritual integrity. In Human Needs 2 and the Nursing Process. Ed. by Yura, H. and Walsh, M.B. Connecticut: Apleton-Century-Crofts, 85-116.

OSTCHEGA, Y. AND JACOB, J.G. 1984. Providing 'safe conduct' - Ilelping your patient cope with cancer. Nursing 84, April, 42-47.

RIEED, P.G. 1986. Religiousness among terminally ill and healthy adults. Research in Nursing and llealth, 9(1):35-41.

SAUNDERS, J.M. AND MCCORKLE, R. 1985. Models of care for persons with progressive cancer. Nursing Clinics of North America, 20(2):365-377.

SIL.BERFARB, P.M., MAURER, L.II. ANI) CROUTHAMI:R, C.S. 1980. Psychosocial aspects of neoplastic disease: I. Functional status of breast cancer patients during different treatment regimes. American Journal of Psychiarry, 137(4):450-455.

SIMS, S.E.R. 1987. Relaxation training as a technique for helping patients cope with the experience of cancer: $\Lambda$ selective review of the literature. Journal of Advanced Nursing, 12(5):583-591.

SIMSEN, B. 1988. Nursing the spirit. Nursing Times, 84(37):31-33.

SKORUPKA, P. \& BOINFT, N. 1982. Primary caregivers' perceptions of nursing behaviors that best meet their needs in a home care hospice setting. Cancer Nursing, 5:371-374.

SMITI, K.S. 1978. The need to love and to be loved. In Human needs and the nursing process. Ed. by Jura, H. and Walsh, M.B. New York: Appleton-Century-Crofts, 171-211.

STOLL, R.I. 1979. Guidelines for spiritual assessment. American Journal of Nursing, 79(9): 1574-1577.
TOUGHILL, E..II. 1984. Sexual counselling for the mastectomy patient. Occupational Ilealth Nursing, 32(8):416-418

WIIISMAN, A.D. \& WORDEN, J.W. 1976-77 The existential plight in cancer: Significance of the first 100 days. International Journal of Psychiary in Medicine, 7(1):1-15.

WOODS, N.F. \& EARP, J.O. 1978. Women with cured breast cancer: $A$ study of mastectomy patients in North Carolina. Nursing Research, 27(5):279-285.

WORTMAN, C.B. 1984. Social support and the cancer patient: Conceptual and methodologic issues. Cancer, 53(10):23.39-2357.

WRIGIIT, L.K. 1985. Life threatening illness. Journal of Psychosocial Nursing, 23(9):7-11.

Neltjie C. van Wyk

D.Soc.Sc. Verpleegkunde, Senior lektor Depariement Verpleegkunde UOVS 